\title{
Engineering Management: The Practical Discipline
}

\author{
Taggart Smith \\ School of Technology, Purdue University
}

A headline in USA Today caught my eye: "Education gaps leave graduates ill-prepared." 1 The lead stated: "College graduates enter the work force with strong technical skills but aren't very good at communicating, being part of a team or accepting ambiguity, among other things." The "other things" included ethics and global awareness. The report was the result of a study done by the Task Force on High-Performance Work and Workers, sponsored by the Business-Higher Education Forum, affiliated with the American Council on Education. ${ }^{2}$ This sentiment was expressed earlier in the halls of The American Society for Engineering Education (ASEE) via the 1995 National Science Foundation report Restructuring Engineering Education, as well as a Prism article on Pennsylvania State University. The university's Leonhard Center for the Innovation and Enhancement of Engineering Education has funded a new leadership minor, which Director Jack Matson described: "There are five basic things the world tells us we need to do to radically improve engineering education: . . . to enhance communication skills, increase international outlook, broaden understanding of business, encourage creativity, and call attention to ethical concerns regarding technology and society." 3

Is the study of engineering management including these improvements? To answer this question and to look at the "differences" in the discipline of engineering management (EM), I polled an assortment of practitioners familiar with field literature to find the most well-known programs. I then asked representatives from the programs to send their most recent plans of study. In this paper I will look for similarities and differences in course requirements for popular programs in engineering management. The search theme is to discover the subject areas important in the preparation of our discipline's graduates, especially the five areas of communication, business, creativity,teamwork, ethics, and international concerns.

\section{Brief History of Engineering Management}

Dr. Dundar F. Kocaoglu, Director of Engineering Management at Portland State University, has made a longitudinal study of the discipline and has written extensively. His paper, "Education for Leadership in Management of Engineering and Technology," 4 describes the origins of the field as an industrial management program at Massachusetts Institute of Technology in 1913. The field grew slowly in terms of developing coursework and in becoming established as a professional area of expertise until the oil crisis of the 1970s. Apparently, so long as conditions remained static, traditional education sufficed; however, when international forces created a changing American business environment and changing technology, engineering management came into its own as an important discipline. Former technical specialists had to become technical managers of people, as well as projects and technology. In short, simply having cutting-edge technology was not enough to keep America on the forefront of business and industry; managing that technology and the resources required to maintain it became important-- 
thus, an increased attention to engineering management.

"Engineering and Technology Management is the discipline addressed to making and implementing decisions for leadership in existing and emerging technologies and their impacts on interrelated systems. Its focus is placed on issues both at the strategic and the operational levels" (p. 79). Dr. Kocaoglu further stated that the foci of different programs varied with the region being served, but generalized that "they all reflect on a discipline starting where Industrial Engineering stops, and going up to a point where Public Policy starts." 


\section{The Scope of Engineering Management}

In detailing the dimensions of the field, Dr. Kocaoglu said that EM included basic and applied research, developing, designing, and implementing the transfer of technology, as well as testing, marketing, and maintaining the technological life cycle, all of which seem to represent the engineering side of the EM house. A second area concerned the subsystems of people, projects, organizations, resources, innovation, and strategy, which seem to represent the managerial side of the EM house. (p. 80)

In a 1991 overview of core and elective EM courses in 80 United States universities, Dr. Kocaoglu lists:

Most frequently offered core courses Most frequently offered electives

$\begin{array}{llll}\text { Operations research } & 43 & \text { Engineering (CE, EE, ME, etc.) } & 43 \\ \text { Accounting } & 38 & \text { MIS } & 37 \\ \text { Economic theory } & 35 & \text { AI/expert systems } & 35 \\ \text { Financial management } & 31 & \text { Project management } & 34 \\ \text { Behavioral science } & 29 & \text { Personnel management } & 34 \\ \text { Project management } & 22 & \text { Quality management } & 33 \\ \text { Strategic planning } & 17 & \text { Operations research } & 32 \\ \text { Projects (group, individual) } & 16 & \text { Database management } & 30 \\ \text { Technology management } & 15 & \text { Economic theory } & 29 \\ \text { Quality management } & 13 & \text { Financial management } & 29 \\ \text { R \& D management } & 13 & \text { Manufacturing management } & 28 \\ \text { Indus/organ. psychology } & 12 & \text { CAD/CAM } & 27 \\ \text { Manufacturing management } & 12 & \text { Indus/organ. psychology } & 27 \\ \text { Case studies } & 11 & \text { Accounting } & 26 \\ \text { Communication } & 11 & \text { Entrepreneurship } & 24 \\ \text { Engineering (CE,EE,ME, } & 10 & \text { Behavioral science } & 23 \\ \text { MIS } & 10 & \text { Forecasting } & 23 \\ \text { Personnel management } & 10 & \text { Industrial relations } & 23 \\ \text { Productivity management } & 10 & \text { Productivity management } & 22\end{array}$

One "difference," then, in engineering management education is that the study of engineering itself is not paramount, but is balanced by the study of various aspects of business, such as finances, personnel, productivity, as well as psychology, entrepreneurship, and behavioral science. Thus, some of the original concerns of this paper are addressed: engineering management broadens understanding of business, and offers education in teamwork, creativity, and global awareness. This education focus is further corroborated by two other well-known engineering management leaders.

Drs. Daniel L. Babcock and Bernard R. Sarchet, University of Missouri-Rolla, in their article, "Is Engineering Management a Profession," questioned the way EM differed from other management specialties. 5

"The engineering manager is distinguished from other managers by the fact that he possesses both an ability to apply engineering principles and a skill in organizing and directing people and projects. He is uniquely qualified for two types of jobs: the management of technical functions (such as design or production) in almost any enterprise, or the management of broader functions (such as marketing or top management) in a high-technology enterprise." (p. 240) 


\section{Engineering Management Programs}

In a 1994-5 study, Dr. Kocaoglu noted that of the 166 EM programs identified, 77 were called Engineering Management, 46 were Management of Technology, 17 were Industrial Management, 8 were Manufacturing Management, and 5 were an MBA with Technology Management. (13 others were titled variously.) 6 Ninety-two EM programs were located in engineering schools, 29 were in business schools, and 33 were in joint engineering- business schools. Sixty-five percent of EM faculty come from engineering and physical science backgrounds, while $29 \%$ come from business and management, and $6 \%$ come from social sciences and other areas of study.

To arrive at coursework descriptions for well-known EM programs, I asked practitioners who had had the opportunity to read field literature over time. These were Dr. Ted Eschenbach, Editor of Engineering Management Journal; Dr. Dundar Kocaoglu, chronicler of EM curricula; and Dr. Jerome Lavelle, whom I am following through the"chairs" of the ASEE

EM Division and who knows everything. What follows is a coursework overview.

\section{Old Dominion University}

Engineering Management, College of Engineering and Technology, Norfolk, Virginia

\section{Core Program}

ENMA420/520

ENMA600

ENMA601

ENMA602

ENMA603

ENMA604

ENMA605

ENMA607

ENMA614
Statistical Concepts in Engineering Management

Monetary Concepts in Engineering Management

Behavioral Concepts in Engineering Management

Technological Data Analysis

Deterministic Decision Methods

Project Management

Project Research

Stochastic Decision Methods

Quality Assurance Management

Elective Courses

Organizational Analysis and Design

Sociotechnical Systems Design

Language, Design, and Management Reliability and Maintainability

Robust Engineering Design

Risk Analysis

Computer Methods and Models

Knowledge Engineering

Production Systems Management

Contemporary Manufacturing Technology

Technology Policy

Architecture of Knowledge and Quality

Qualitative Research
Organizational Communication

Inter-Cultural Issues in Organizations

Parametric Cost Engineering

Discrete Event Simulation

Systems Theory and Cybernetics

Applications of Neural Networks

Computer Integrated Manufacturing

Human Factors Engineering

Policy Modeling

Quantitative Research Design

(Electives in other Colleges may be selected.)

Degree Concentrations/Fields of Study

Master of Engineering Management (M.E.M.) M.S. in Engineering Management M.E. in Operations Research \& Systems Analysis Ph.D. in Engineering Management Certificate of Professional Study in Engineering Management (post-masters' certificate) ${ }^{7}$ 


\section{Portland State University}

Engineering Management, School of Engineering and Applied Science, Portland, Oregon

Core Program

EMgt 520 Management of Engineering and Technology

EMgt 530 Decision Making in Engineering and Technology Management

EMgt 540 Operations Research in Engineering and Technology Management

EMgt 545 Project Management in Engineering and Technology

EMgt 555 Technology Marketing

EMgt 510 Communication and Team Building or Mgmt 550 Organizational Management

EMgt 535 Engineering Economic Analysis or Actg 511 Financial Accounting

EMgt 590 Engineering Management Synthesis or M.S. Thesis or Special Projects 8

\section{Elective Courses}

Unit Operations in Environmental Engineering

Computer Simulations of Industrial Facilities

Strategic Planning in Engineering Management

Project Scheduling \& Network Analysis

Manufacturing Systems Management

Manufacturing Systems Simulation

Reengineering the Technical Enterprise

Research Methods for Engineering Management
Engineering Statistics

International Financial Management

Productivity Analysis

Manufacturing Systems Engineering

Intelligent Manufacturing Systems

TQM: Total Quality Management

Expert Systems in Engineering

(24 credits from 107 electives allowed)

Degree Concentrations/Fields of Study

M.S. Engineering Management Ph.D. in Systems Science--Engineering Management

Technology Management Decision Theory

Operations Research Project Management

Manufacturing Management Technology Planning

Technological Innovations Knowledge-based Systems

\section{Stevens Institute of Technology}

Engineering Management, Castlepoint on the Hudson, Hoboken, New Jersey

\section{Core Courses}

\begin{tabular}{lll} 
EM & $301 / 302 / 303$ & Management of Design I/II/III \\
EM & 365 & Statistics for Engineers \\
EM & 350 & Production/Operations Management \\
EM & 357 & Elements of Operations Research \\
EM & 380 & Engineering Management Lab \\
EM & 415 & Engineering Management Design Project \\
EM & 460 & Quality Management \\
EM & 466 & Statistical Quality Control \\
EM & 470 & Engineering Management \\
EM & 485 & Human Factors \\
& & (Required courses from E, EE, CH, CE, Math, ME, PE, PEP) \\
\hline
\end{tabular}


Group Dynamics

MIS/Computer Applications

Introduction to Individual Psychology

Microeconomics
Elective Courses

Transport

Materials Processing

Microeconomics

Humanities (18 credits)

Degree Concentrations/Fields of Study

B.E. in Engineering Management M.S. in Concurrent Engineering M.S. in Management

M.S. in Applied Psychology

Ph.D. in Information Management

Ph.D. in Concurrent Engineering Ph.D. in Applied Psychology

\section{University of Missouri-Rolla}

Engineering Management, Rolla, Missouri

\section{Core Courses}

Emgt 209 Engineering Economy and Management

Emgt $230 \quad$ Management Accounting Systems

Emgt 251 Marketing Management

Emgt 252 Financial Management

Emgt 260 General Management-Design and Integration

Emgt 282 Production Management

(Required courses in CH, PHY, Math, Hmnt (24 cr.), E, EG, BE, ME, EE, + emphasis areas: manufacturing, packaging, industry, quality, management)

Elective courses

Plant Layout

Solid Waste

Value Analysis

Neural Networks

Total Quality Management

Project Management

Statistical Process Control

Experimentation in EM

Management for Engineers

Technical Enterprise

Legal Environment

Work Design

Safety Engineering Management

(20 other Emgt courses available in catalog) 9

Degree Concentrations/Fields of Study

B.S., M.S. and Ph. D. in Engineering Management

Emphasis Areas: Manufacturing Engineering, Packaging Engineering, Industrial Engineering, Quality Engineering, Management of Technology 


\section{Conclusions and Recommendations}

The original query of this paper concerned whether engineering management programs were enhancing communication skills, increasing international outlook, broadening understanding of business, encouraging creativity, encouraging teamwork, and calling attention to ethical concerns regarding technology and society, since traditional engineering education seems not to be addressing these areas. I think the answer is: the curricular opportunity is there. Different programs seem to emphasize different strengths: Old Dominion offers graduate degrees from a panoply of course offerings taught within the department; Portland State offers the most latitute in coursework (107 electives) networking throughout the university; Stevens also networks with other departments and schools to offer a engineering-oriented program; and UMR looks as though it should have 100 faculty just to teach their undergraduate courses. My thanks to Larry Richards (Old Dominion), Dundar Kocaoglu (Portland State), Don Merino (Stevens), and Steve Raper (UMR) for sending the material for this paper.

My final thought is this: if engineering management is the discipline for the 21st century, how can we as practitioners best get the message out? My recommendation is a compilation of the best programs we have, much in the manner of The Fiske Guide to Colleges, making engineering management a subject to discuss among high school and college counselors, as well as university consortia world wide.

\section{Bibliographic Information}

1 Marklein, M. B. (1997, February 14). Education gaps leave graduates ill-prepared. USA Today, p. 13D.

2 Task Force on High-Performance Work and Workers. (1997, January). Spanning the Chasm: Corporate and academic cooperation to improve work-force preparation. Washinton, DC: Business-Higher Education Forum.

3 Schwartz, R. A. (1996, March). Providing the leadership edge. ASEE Prism , 5 (7), 9.

4 Kocaoglu, D. F. (1991). Education for leadership in management of engineering and technology. PICMET '91 - Portland International Conference on Management of Engineering and Technology (pp. 78-83). New York, NY: Institute of Electrical and Electronics Engineers.

5 Babcock, D. L., \& Sarchet, B. R. (1980). Is engineering management a profession? 1980 IEEE Engineering Management Conference Record (pp. 238-241). New York, NY: Institute of Electrical and Electronics Engineers.

6 Kocaoglu, D. F. (1996). Engineering management: Educational strategies for leadership in technology management. Industry \& Higher Education, 332-336.

7 Department of Engineering Management, College of Engineering and Technology. (no date). Master of Engineering Management and Master of Science Programs [Brochure]. Norfolk, VA: Author.

8 Portland State University 1995-96. (Summer, 1995). Portland State University Bulletin, 29, (4), pp. 390-391.

${ }^{9}$ University of Missouri-Rolla. (1996-97). The University of Missouri Undergraduate Catalog 1996-97, pp. 55-57, 120-123. 


\section{Biographical Information}

TAGGART SMITH, Ed.D.

Associate Professor, Organizational Leadership, School of Technology, Purdue University.

Past Chair: ASEE IL/IN Section, Current Secy/Treasurer: Engineering Management Division.

Phone: (765) 494-6391 FAX: (765) 496-2519 email: tesmith@tech.purdue.edu

Address:1420 Knoy Hall of Technology, Purdue University, West Lafayette, IN 47907-1420. 